\title{
Prevalence and Antibiogram of Salmonella Enterica Isolated from Raw Dromedary Camel Milk in Matrouh Governorate, Egypt
}

\author{
Elham Saeed $^{1 *}$, Amr A. Amer ${ }^{2}$, Hany G. Keshta ${ }^{3}$ and Eman Khalifa ${ }^{4}$ \\ ${ }^{1}$ Food Hygiene Department, Faculty of Veterinary Medicine, Matrouh University, Egypt \\ ${ }^{2}$ Food Hygiene Department, Faculty of Veterinary Medicine, Alexandria University, Egypt \\ ${ }^{3}$ Animal Medicine Department, Faculty of Veterinary Medicine, Matrouh University, Egypt \\ ${ }^{4}$ Microbiology Department, Faculty of Veterinary Medicine, Matrouh University, Egypt \\ *Corresponding author: elham_saeed@mau.edu.eg
}

\begin{tabular}{|c|c|c|}
\hline Article History: 21-327 & Received: 06-Jun-21 & Accepted: $15-A u g-21$ \\
\hline \multicolumn{3}{|l|}{ ABSTRACT } \\
\hline 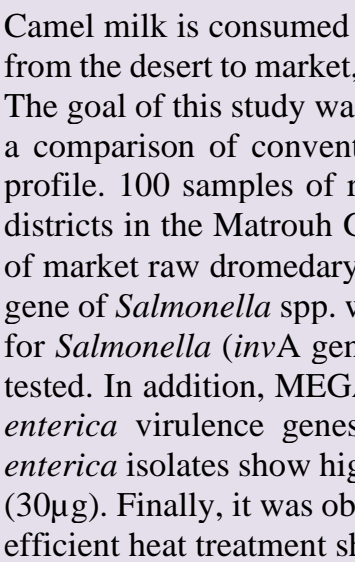 & $\begin{array}{l}\text { ocessed in Matrouh Governorate, due to a lack of re } \\
\text { ell as insufficient hygiene procedures along the milk } \\
\text { letermine the prevalence of Salmonella enterica in r } \\
1 \text { and molecular Salmonella enterica identification } \\
\text { amel milk ( } 50 \text { from markets and farms each) were } \\
\text { morate, Egypt, for microbiological examination. Sa } \\
\text { el milk and } 0 \% \text { of farm raw dromedary camel milk } \\
\text { ound in } 6 \text { and } 0 \text { of the tested isolates, respectively, by } \\
\text { almonella spp. or enterica virulence genes (stn and } \\
\text { software was used to perform gene sequencing and } \\
\text { lmonella enterica antibiotic resistance pattern wa } \\
\text { tibiotic resistance specially against Rifamycin ( } 30 \mu \mathrm{g} \\
\text { d that the hygienic quality of raw camel milk was at } \\
\text { be adopted to maintain food safety. }\end{array}$ & $\begin{array}{l}\text { n facilities during transport } \\
\text { til it reaches the customers. } \\
\text { dary camel milk, as well as } \\
\text { quencing, and antibiogram } \\
\text { d at random from different } \\
\text { enterica was found in } 10 \% \\
\text { ndard methods. The unique } \\
\text { ar identification using PCR } \\
\text { ere found in all the isolates } \\
\text { etic analysis of Salmonella } \\
\text { ed. Moreover, Salmonella } \\
\text { omycin }(15 \mu \mathrm{g}), \text { Novobiocin } \\
\text { strict hygienic practice and }\end{array}$ \\
\hline
\end{tabular}

Key words: Antibiogram, Camel milk, PCR, Phylogenetic analysis, Salmonella enteritidis, Salmonella Kentucky, Sequencing, Virulence genes

\section{INTRODUCTION}

Matrouh Governorate is one of the arid areas in Egypt, this makes camel breeding a key in the food security of human by providing milk and meat. Because raw dromedary camel milk is a necessary food in tropical countries, especially in Africa. It is rich in nutritive components needed for human health such as protein, fat, lactose, ash, and vitamins.

Salmonella is the major reason of foodborne disease in many countries around the world leading to diarrhea and abdominal cramps. Salmonella infection may come from raw or unpasteurized milk and milk product consumption (Karshima et al. 2013; Soliman et al. 2020). About 94\% of salmonellosis cases occur due to food, which can be transmitted in two ways. Firstly, by direct contact with infected or carrier animals and secondly from human to human by ingestion of food that is contaminated by human feces carrying Salmonella (Elbayoumi et al. 2019; Shaw et al. 2020). Every year, one out of every ten people gets sick, and foodborne diseases claim the lives of 33 million healthy people. Immunocompromised patients, such as the elderly, children, and pregnant women, may be at higher risk. Diarrhea is the most common symptom of eating contaminated food; 550 million people get sick each year, including 220 million under the age of five. Salmonellosis is a common cause of diarrhea in people all over the world (WHO 2018).

The respective incidence of Salmonella spp. in raw dromedary camel milk was $24 \%$ of 33 samples in the Qassim region in middle Saudi Arabia, $0.4 \%$ of 40 samples in Al-Alhsa Governorate, Saudi Arabia, 13\% of 31 samples in Southern Morocco and 30.5\% of 104 samples from Garissa County, Kenya was reported by (EL-Ziny and AL-

Cite This Article as: Saeed E, Amer AA, Keshta HG and Khalifa E, 2022. Prevalence and antibiogram of Salmonella Enterica isolated from raw dromedary camel milk in Matrouh Governorate, Egypt. International Journal of Veterinary Science 11(2): 168-174. https://doi.org/10.47278/journal.ijvs/2021.088 
Turki 2013; El-Demerdash and Al-Otaibi 2012; Ismaili et al. 2016; Noor et al. 2020). On the other hand, Aly and Elewa (2014) and Bassuony et al. (2014) reported that Salmonella spp. could not found in Egyptian raw camel milk samples. In the US, CDC records every year 1.35 million Salmonella infections, 26.500 go to hospitals and stay for a period while 420 cases die. Food is the major cause of these cases (CDC 2016).

The invA and stn gene sequencing has an important role in Salmonella identification, discover the new species and gives a wide scope of analysis. Gene sequencing is a rapid technique for bacterial identification of unknown phenotypes (Kaabi and AL-Yassari 2019). Raw dromedary camel milk traditionally consumed without any processing in Matrouh Governorate. There were no hygienic measures or cleaning protocol to control the biohazards that may occur during retail until reach consumer. Foodborne salmonellosis has persisted as an ignored zoonotic disease in Egypt and other growing countries. The current investigation was intended to spotlight the incidence of Salmonella spp. in raw dromedary camel milk collected from different districts in Matrouh Governorate, Egypt. As well as screening for possible presence of its specific gene, virulence genes (which confirmed by gene sequencing and phylogenetic analysis) and antibiotic-resistant pattern.

\section{MATERIALS AND METHODS}

\section{Ethical Approval}

This study has prior approval from institutional animal care and use committee, Alexandria University (ALEXUIACUC) member of ICLAS, approval number: AU 005 20190715 MS (1) 02.

\section{Collection of Samples}

One hundred samples of raw dromedary camel milk were randomly collected from the Matrouh Governorate (fifty samples from different markets and fifty samples from farms in Siwa, Salloum, Almtani (Dardouma area), Sidi-Barani in Matrouh desert ways) throughout 4 months (from October 2019 to January 2020). Each sample (250 $\mathrm{ml}$ ) was collected in a sterile plastic-stoppered cups. The samples were transferred to Microbiology Department, Faculty of Veterinary Medicine, Matrouh University in icebox $4 \pm 1^{\circ} \mathrm{C}$ within 2-4hours.

\section{Isolation and Identification of Salmonella species (ISO 2017)}

Twenty-five $\mathrm{ml}$ of each examined raw camel sample were transferred into $225 \mathrm{ml}$ of buffered peptone water (BPW) pre-warm to room temperature. The samples were homogenized and incubated between $34^{\circ} \mathrm{C}$ and $38^{\circ} \mathrm{C}$ for $18 \mathrm{~h}$. Aseptically, $0.1 \mathrm{ml}$ of cultured buffered peptone water transported into $10 \mathrm{ml}$ of Rappaport-Vassiliadis medium with soya (RVS broth). which was incubated at $41.5^{\circ} \mathrm{C}$ for 24h. Loopful of RVS broth was streaked onto the first selective medium Xylose lysine deoxycholate agar (XLD agar), and the second selective medium SalmonellaShigella (SS) Agar. The inoculated plates were incubated inverted at $37^{\circ} \mathrm{C}$ for $24 \pm 3 \mathrm{~h}$. Typical colonies of Salmonella grown on XLD agar had a black center and a lightly transparent zone of reddish color due to the color change of the indicator, while on SS agar had transparent colorless colonies (Colonies of Salmonella spp. may appear with or without black centers).

\section{Biochemical Identification of Suspected Salmonella Colonies (ISO 2017)}

The suspected colonies were selected for subculture and confirmation. The colonies were streaked onto the surface of dried non-selective medium (Nutrient agar) and incubated between $35^{\circ} \mathrm{C}$ for $24 \mathrm{~h}$. for identification by triple sugar/iron agar, urea agar, L-Lysine decarboxylation medium (LDC), detection of $\beta$-galactosidase, indole reaction.

\section{Serological Identification of Suspected Salmonella Colonies (ISO 2014)}

Serotyping of Salmonella according to White Kauffmann le minor scheme Grimont and Weill the following antisera: (A-67), + Vi omnivalent. The detection of the presence of Salmonella antigens were tested by slide agglutination with the appropriate sera, from pure colonies and after auto-agglutinable strains had been eliminated.

\section{Molecular Identification using Conventional and Multiplex PCR}

The molecular identification was carried out in the Reference Laboratory for Veterinary Quality Control on Poultry Production, Animal Health Research Institute, Giza, Egypt. The DNA extraction executed by QIAamp DNA Mini Kit, Catalogue no.51304 rendering to the manufacturer's instructions. The PCR procedures for each primer pair were carried out based as mentioned in Table 1 and Table 2. The PCR products were electrophoresed on $1 \%$ agarose gel (Sambrook et al. 1989) then transferred into a UV cabinet. The gel was snapped by gel documentation system (Alpha Innotech) and the figures were examined computerized.

\section{Gene Sequencing and Phylogenetic Analysis}

The sequencing was carried out in Elim Biopharmaceuticals, USA. A purified PCR product was sequenced in the forward and reverse directions on an Applied Biosystems 3130 automated DNA Sequencer (ABI, 3130, USA). Using a ready reaction big dye Terminator V3.1 cycle sequencing kit (Perkin-Elmer/Applied Biosystems, Foster City, CA), with Cat. No. 4336817.

A BLAST® analysis (Basic Local Alignment Search Tool) (Altschul et al. 1990) was primarily performed to create sequence identity to GenBank accessions. The sequence reaction was done along with the instruction of the producer. The results of nucleotide sequencing were submitted to GenBank via BankIt (GenBank). The sequences were accepted and received accession numbers. Phylogenetic analysis was conducted using MEGA version $\mathrm{X}$ (Kumar et al. 2018) by comparing resultant sequences with the other sequences available in GenBank. The tree built according to UPGMA.

\section{Antibiotic Susceptibility Testing (AST)}

The antibiotics exposure of isolates were carried by the agar disk diffusion method (CLSI 2018). The isolates were subjected to susceptibility test against Norfloxacin $(10 \mu \mathrm{g})$, Cefoperazone $(75 \mu \mathrm{g})$, Pefloxacin $(5 \mu \mathrm{g})$, Ciprofloxacin $(5 \mu \mathrm{g})$, Nitrofurantoin $(300 \mu \mathrm{g})$, Tobramycin $(10 \mu \mathrm{g})$, Rifamycin 
Int J Vet Sci, 2022, 11(2): 168-174.

Table 1: Oligonucleotide primers sequences (Metabion, Germany)

\begin{tabular}{lllcc}
\hline Target bacteria & Target gene & Sequence & Amplified product & Reference \\
\hline Salmonella & invA & F GTGAAATTATCGCCACGTTCGGGCAA & 284bp & Olivera et al. (2003) \\
& & R TCATCGCACCGTCAAAGGAACC & 164bp & Hojati et al. (2013) \\
& fim $\mathrm{H}$ & F GTGCCAATTCCTCTTACCGTT & & Murugkar et al. (2003) \\
& stn & R TGGAATAATCGTACCGTTGCG & 617bp & \\
& F TTG TGT CGC TAT CAC TGG CAA CC & & \\
& R ATT CGT AAC CCG CTC TCG TCC & &
\end{tabular}

Table 2: Temperature and time conditions of primers during PCR

\begin{tabular}{|c|c|c|c|c|c|c|c|}
\hline Target bacteria & Target gene & Primary denaturation & Secondary denaturation & Annealing & Extension & No. of cycles & Final extension \\
\hline Salmonella & invA & $94^{\circ} \mathrm{C} 3 \min$ & $94^{\circ} \mathrm{C} \mathrm{30s}$ & $55^{\circ} \mathrm{C} 30 \mathrm{~s}$ & $72^{\circ} \mathrm{C} 30 \mathrm{~s}$ & 35 & $72^{\circ} \mathrm{C} 7 \mathrm{~min}$ \\
\hline spp. & $\operatorname{fim} \mathrm{H}$ & $94^{\circ} \mathrm{C} 3 \mathrm{~min}$ & $94^{\circ} \mathrm{C} 30 \mathrm{~s}$ & $59^{\circ} \mathrm{C} \mathrm{30s}$ & $72^{\circ} \mathrm{C} 30 \mathrm{~s}$ & 35 & $72^{\circ} \mathrm{C} 7 \mathrm{~min}$ \\
\hline & Stn & $94^{\circ} \mathrm{C} 3 \mathrm{~min}$ & $94^{\circ} \mathrm{C} 30 \mathrm{~s}$ & $59^{\circ} \mathrm{C} 40 \mathrm{~s}$ & $72^{\circ} \mathrm{C} 45 \mathrm{~s}$ & 35 & $72^{\circ} \mathrm{C} 10 \mathrm{~min}$ \\
\hline
\end{tabular}

*Control positive and negative strains were represented by field samples that were previously confirmed to be positive or negative by PCR for the related genes in the Reference Laboratory for Veterinary Quality Control on Poultry Production, Animal Health Research Institute.

Table 3: Prevalence of Salmonella enterica isolated from examined raw dromedary camel milk samples

\begin{tabular}{|c|c|c|c|c|c|}
\hline \multirow[t]{3}{*}{ Source } & \multirow[t]{3}{*}{ No. of examined samples } & \multicolumn{4}{|c|}{ Salmonella enterica } \\
\hline & & \multicolumn{2}{|c|}{ Conventional methods } & \multicolumn{2}{|c|}{ Molecular identification } \\
\hline & & No. & $\%$ & No. & $\%$ \\
\hline Market milk & 50 & 5 & 10 & 3 & 6 \\
\hline Farm milk & 50 & 0 & 0 & 0 & 0 \\
\hline Total & 100 & 5 & 5 & 3 & 3 \\
\hline
\end{tabular}

Table 4: Antimicrobial susceptibility profile of Salmonella enterica isolated from examined raw camel milk samples.

\begin{tabular}{|c|c|c|c|c|c|c|c|}
\hline \multirow{3}{*}{ Antimicrobial agents } & \multirow{3}{*}{$\begin{array}{l}\text { Sensitivity disc } \\
\text { conc. }(\mu \mathrm{g})\end{array}$} & \multicolumn{6}{|c|}{ Salmonella enterica sub enterica $(\mathrm{n}=3)$} \\
\hline & & \multicolumn{2}{|c|}{ Susceptible } & \multicolumn{2}{|c|}{ Intermediate } & \multicolumn{2}{|c|}{ Resistant } \\
\hline & & No. & $\%$ & No. & $\%$ & No. & $\%$ \\
\hline Norfloxacin (NOR) & 10 & 3 & 100 & 0 & 0 & 0 & 0 \\
\hline Cefoperazone (CEP) & 75 & 3 & 100 & 0 & 0 & 0 & 0 \\
\hline Pefloxacin (PEF) & 5 & 2 & 66.6 & 1 & 33.3 & 0 & 0 \\
\hline Ciprofloxacin (CIP) & 5 & 2 & 66.6 & 1 & 33.3 & 0 & 0 \\
\hline Nitrofurantoin $(\mathrm{F})$ & 300 & 3 & 100 & 0 & 0 & 0 & 0 \\
\hline Tobramycin (TOB) & 10 & 1 & 33.3 & 1 & 33.3 & 1 & 33.3 \\
\hline Rifamycin (RF) & 30 & 0 & 0 & 0 & 0 & 3 & 100 \\
\hline Cefoxitin (FOX) & 30 & 0 & 0 & 2 & 66.6 & 1 & 33.3 \\
\hline Rifampicin (RD) & 5 & 0 & 0 & 0 & 0 & 3 & 100 \\
\hline Streptomycin (S) & 10 & 2 & 66.6 & 1 & 33.3 & 0 & 0 \\
\hline Neomycin $(\mathrm{N})$ & 30 & 0 & 0 & 2 & 66.6 & 1 & 33.3 \\
\hline Chloramphenicol (C) & 30 & 3 & 100 & 0 & 0 & 0 & 0 \\
\hline Ofloxacin (OFX) & 5 & 3 & 100 & 0 & 0 & 0 & 0 \\
\hline Levofloxacin (LEV) & 5 & 2 & 66.6 & 1 & 33.3 & 0 & 0 \\
\hline Piperacilin (PRL) & 100 & 3 & 100 & 0 & 0 & 0 & 0 \\
\hline Erythromycin (E) & 15 & 0 & 0 & 0 & 0 & 3 & 100 \\
\hline Novobiocin (NV) & 30 & 0 & 0 & 0 & 0 & 3 & 100 \\
\hline
\end{tabular}

$(30 \mu \mathrm{g})$, Cefoxitin $(30 \mu \mathrm{g})$, Rifampicin $(5 \mu \mathrm{g})$, Streptomycin $(10 \mu \mathrm{g})$, Neomycin $(30 \mu \mathrm{g})$, Chloramphenicol $(30 \mu \mathrm{g})$, Ofloxacin $(5 \mu \mathrm{g})$, Levofloxacin $(5 \mu \mathrm{g})$, Piperacillin $(100 \mu \mathrm{g})$, Erythromycin $(15 \mu \mathrm{g})$, Novobiocin $(30 \mu \mathrm{g})$. The regions of complete inhibition were measured and taken after incubation at $35 \pm 2{ }^{\circ} \mathrm{C}$ for $24 \mathrm{~h}$. Determination of multiple antibiotic resistance (MAR) index (Krumperman 1983).

Multiple antibiotic resistance (MAR) index was measured for all isolate by using the formula $M A R=a / b$, where (a) signifies the number of antibiotics to which the test isolate depicted resistance and (b) represents the total number of antibiotics to which the test isolate has been estimated for susceptibility. If the MAR is higher than 0.2 , this indicated that the isolate was originated from high-risk source of contamination and the abuse of antibiotics, while if the MAR is lower than 0.2, this strain was identified from an area where antibiotics were used rarely or never used.

\section{RESULTS}

The data in the Table 3 and Fig. 1 pointed out that Salmonella enterica could be isolated in $10 \%(5 / 50)$ and $6 \%(3 / 50)$ of inspected market raw dromedary camel milk by conventional and molecular identification, respectively. While it failed to be found in farm raw dromedary camel milk. While Fig. 2 showed that stn and fimH Salmonella virulence genes were found in all examined isolates.

Salmonella kentucky and Salmonella enteritidis forward sequence phylogenetic analyzed Fig. 3 showed that the Salmonella kentucky (MT478118) and Salmonella enteritidis (MT460418) relations with others Salmonella spp. in different countries around world.

The results in Table 4 and Table 5 reveal the antimicrobial susceptibility profile of Salmonella enterica subsp. enterica isolated from raw camel milk. Accordingly, Salmonella enterica subsp enterica isolates showed the highest resistance against Rifamycin $(5 \mu \mathrm{g})$, Erythromycin 


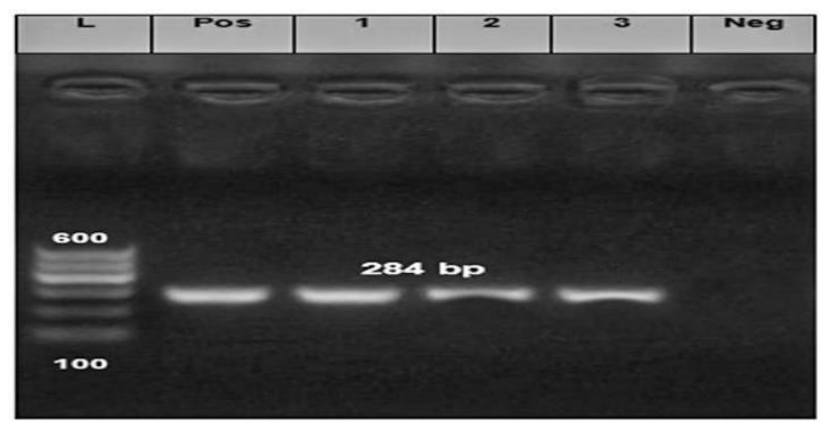

Fig. 1: Electrophoretic gel imaging of PCR for Salmonella invA gene (284bp), Lane M: DNA molecular weight marker (100bp plus ladder), Lane Pos: control positive strain, Lane Neg: control negative strain*, Lanes $(1,2,3)$ : represent positive strains. Lanes (1-3): represent market raw camel milk isolates.

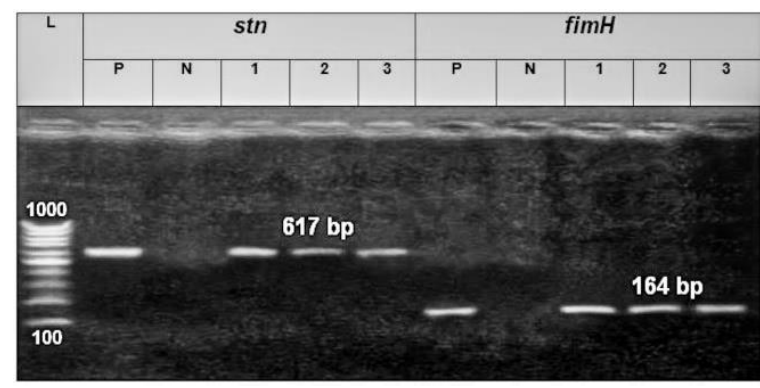

Fig. 2: Electrophoretic gel imaging of PCR for Salmonella virulence genes, (A) Multiplex PCR of stn gene (617bp) and fim $\mathrm{H}$ gene (164bp), Lane L: DNA molecular weight marker (100bp plus ladder), Lane P: control positive strains*, Lane N: control negative strains*, Lanes $(1,2,3)$ : represent positive strains for both genes. Lanes (1-3): represent market raw camel milk isolates.

Table 5: Antibiotics resistance profile and multiple antibiotics resistance (MAR) index of Salmonella enterica isolated from examined raw camel milk samples

\begin{tabular}{|c|c|c|c|c|}
\hline \multirow[t]{2}{*}{ Organism/origin } & \multicolumn{2}{|c|}{ Multidrug resistance M. Os* } & \multirow[t]{2}{*}{ Resistance pattern(a) } & \multirow[t]{2}{*}{ MAR index ** } \\
\hline & No. & $\%$ & & \\
\hline \multicolumn{5}{|c|}{ Salmonella enterica subsp. Enterica } \\
\hline Market milk & 1 & 33.34 & TOB, RF, FOX, RD, N, E, NV & 0.412 \\
\hline Market milk & 2 & 66.66 & RF, RD, PRL, E, NV & 0.294 \\
\hline Farm milk & 0 & 0 & - & - \\
\hline
\end{tabular}

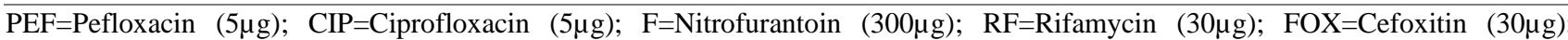
$\mathrm{RD}=$ Rifampicin $(5 \mu \mathrm{g}) ; \mathrm{S}=$ Streptomycin $(10 \mu \mathrm{g}) ; \mathrm{N}=$ Neomycin $(30 \mu \mathrm{g}) \mathrm{C}=$ Chloramphenicol $(30 \mu \mathrm{g}) ; \mathrm{LEV}=\mathrm{Levofloxacin}(5 \mu \mathrm{g})$; $\mathrm{PRL}=$ Piperacillin $(30 \mu \mathrm{g})$; E=Erythromycin $(15 \mu \mathrm{g})$; NV Novobiocin $(30 \mu \mathrm{g})$; TOB=Tobramycin $(10 \mu \mathrm{g})$ : *M. Os: Microorganisms; ** MAR index $=a$ / b; a: represents the number of antibiotics to which the test isolate showed resistance: $b$ : represents the total number of antibiotics to which the test isolate has been evaluated for susceptibility.

$(15 \mu \mathrm{g})$, Novobiocin $(30 \mu \mathrm{g})$. In contrast, the isolates possessed the highest susceptibility against Norfloxacin $(10 \mu \mathrm{g})$, Cefoperazone $(75 \mu \mathrm{g})$, Nitrofurantoin $(300 \mu \mathrm{g})$, Chloramphenicol $(30 \mu \mathrm{g})$, Ofloxacin $(5 \mu \mathrm{g})$, Piperacillin $(100 \mu \mathrm{g})$. The MAR values were ranged from 0.294 to 0.412 of the tested isolates (17 antibiotic agents).

\section{DISCUSSION}

Camel milk is a vital source of nourishment and a cure for the population in many arid regions. Raw camel milk can be contaminated at any stage of production and processing; therefore, it may lose its quality and safety standards. Table 3 showed that Salmonella enterica subsp. enterica could be isolated from market raw camel milk. Almost all raw camel milk samples related to the farms were complied with ES (154-1/2005) which stated that raw milk should be free from Salmonella enterica subsp. enterica. The prevalence of Salmonella enterica subsp. enterica in the current study was quite lower than those mentioned by Noor et al. (2020) who found that the incidence of Salmonella spp. in examined raw camel milk samples was $30.5 \%$.

The most frequent cause of Salmonella enterica contamination in market milk samples is unhygienic conditions of milking and packaging of milk. Moreover, there are other possible sources of contamination such as the dirty marketing environment, transportation, inexperience of sanitation during handling of milk and lack of refrigeration might lead to elevation in the bacterial load camel milk (Hassan et al. 2015). Furthermore, raw camel milk can be contaminated with Salmonella spp. during collection, packaging, transportation, and markets retailing by contacting with faces of infected or carrier animals and humans (Shaw et al. 2020).

The conventional techniques are considered as standard methods for recognition of foodborne pathogens. They have been extensively used because they are effective and cheap. They can give data on the kind, count and nature of the microbes present in the food sample (Zhao et al. 2016). Nevertheless, they need a lot of workers, require time and they are often unsatisfactory (Yu et al. 2016).

Regarding to Fig. 2 Salmonella enterica isolates carried both genes of virulence (stn and fim $\mathrm{H}$ ). Uchiya et al. (2019) reported that fim $\mathrm{H}$ is an adhesive protein and responsible for the adhesion of bacteria to the host cell receptors during the host tissue invasion process (Kuźmińska-Bajor et al. 2015).

The stn gene plays a crucial role in the pathogenicity and severity of infection to the target host. It used for detection and identification of Salmonella spp. because it is existing in all serotypes of Salmonella spp. In addition, it is important for Salmonella enterotoxicity (Mahmoud et al. 2020).

The molecular identification is a different way for detection of pathogens because it is specific, sensitive, and fast (Zhao et al. 2014). The identification system based on molecular genetic methods is more accurate than phenotypic techniques and gives more correct systematic data about a certain strain (Henri et al. 2016).

The use of gene sequencing developed the food-borne infections monitoring and public health surveillance systems. It represents an alternative method used to characterize Salmonella strains (serotyping, virulotyping, antimicrobial resistance, and phylogenies) through one workflow more quickly and professionally compared to conventional methods (Hassena et al. 2021). 
Int J Vet Sci, 2022, 11(2): 168-174.

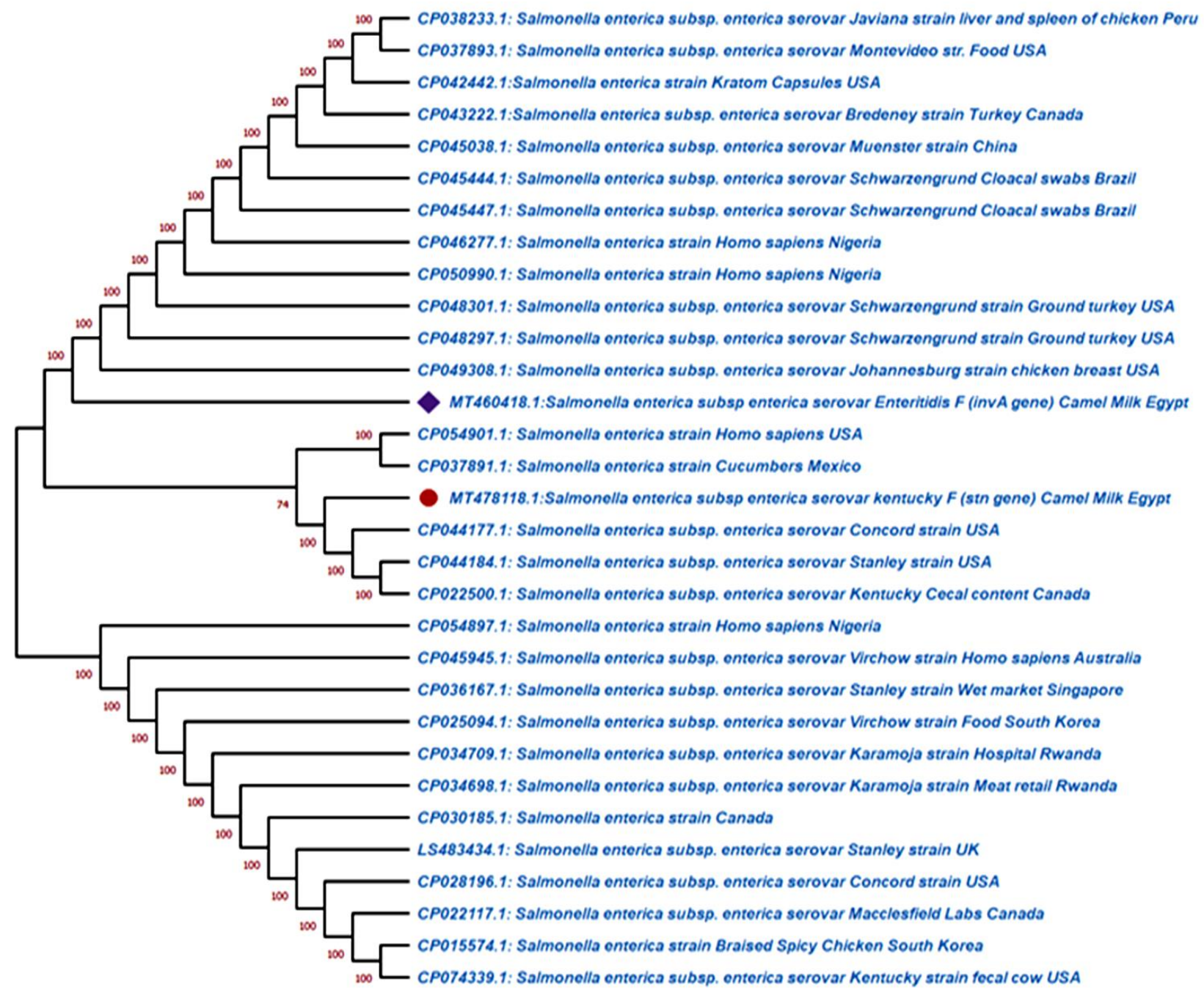

Fig. 3: Phylogenetic tree for the forward sequence of stn of Salmonella Kentucky and invA gene of Salmonella enteritidis based on the DNA nucleotide sequence compared with the other Salmonella enterica strains from different sources and countries listed on GenBank according to UPGMA test.

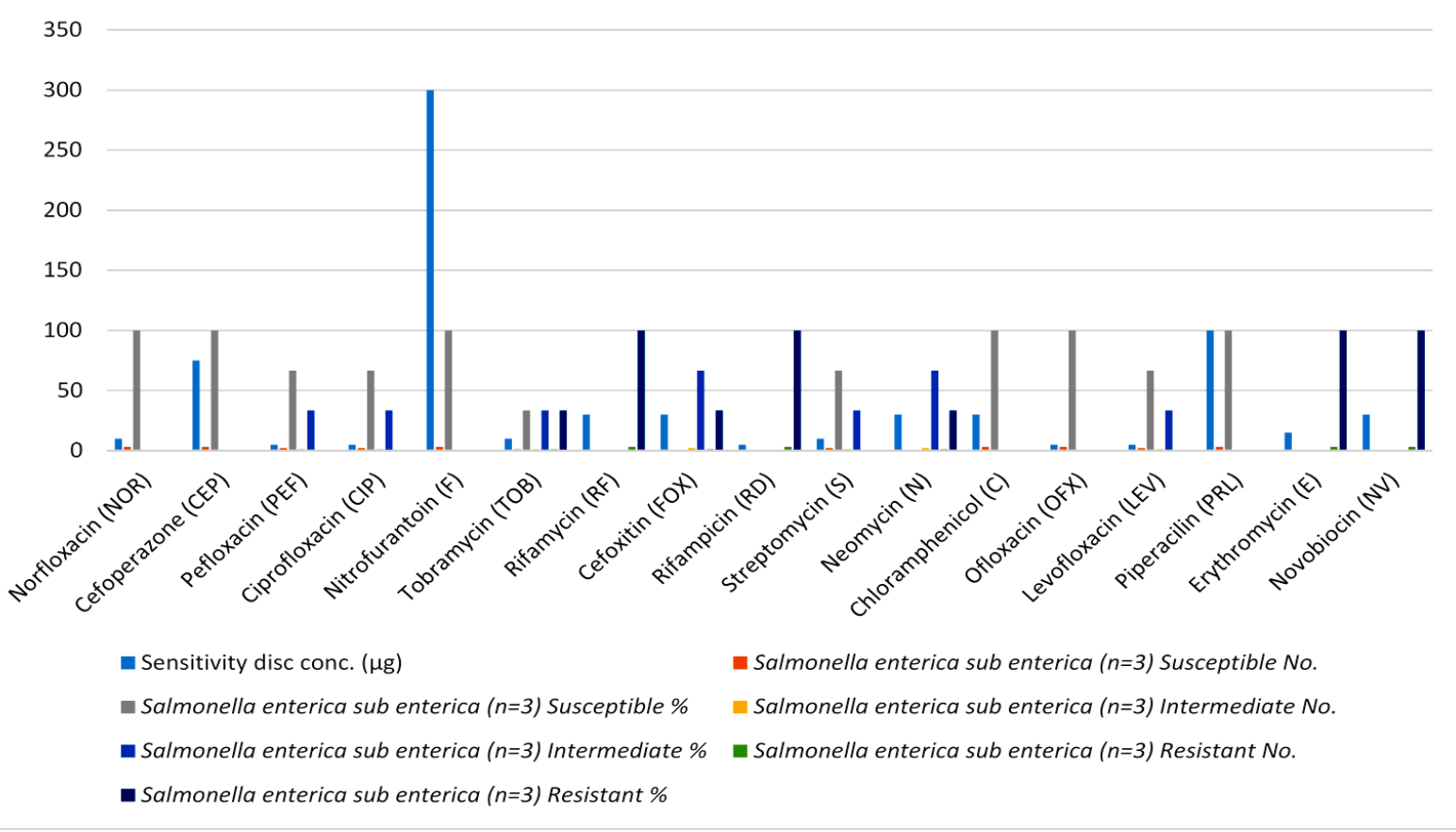

Fig. 4: Antibiotics susceptibility profile of Salmonella enterica isolated from examined raw camel milk samples. 
Salmonellosis caused by Salmonella spp. The symptoms of salmonellosis are abdominal cramps, diarrhea and sometimes vomiting. The symptoms are usually elapsed from 6-72 hours after ingestion of bacteria and remain for 2-7 days. The severity of disease is variable which may be mild with self-curing without any medications but in old age and immunocompromised people can become a life-threatening disease. About 60$80 \%$ of all salmonellosis cases are known as sporadic cases or not diagnosed at all (WHO 2018).

Salmonella can be found in the GIT of human and animal, which can infect people through handling of infected animals or their manure in addition to their premises. Salmonellosis can be occurred via consumption of contaminated raw milk, raw meat, egg, water, fruit, and Vegetables (CDC 2016).

Fig. 3 showed that the Salmonella Kentucky (MT478118.1) show high similarity to Salmonella enterica subsp. enterica serovar Kentucky (CP022500.1) which isolated from chickens cecal content in Canada by $100 \%$ while Salmonella enteritidis show high similarity to highly similarity to Salmonella enterica subsp. enterica serovar Johannesburg strain (CP049308.1) which isolated from chicken breast in USA by $100 \%$. Which gives indications about the variety of sources and methods that Salmonella species could be transmitted through it and cause diseases. In addition, antibiotic resistance could pass through food that are contaminated with resistant microorganisms.

Sequencing is very significant for the formation of global network among foodborne pathogens such as Salmonella spp. Furthermore, it is used to identify unknown genomes and so it is useful to recognize the multiyear and multistate outbreaks (Byrne et al. 2014; CDC 2016).

The quality of data is now a challenge for the public health and food safety communities, as incorrect or missing metadata dramatically reduces the utility of genomic data (Robertson et al. 2018).

Fig. 4 and Table 5 recorded that Salmonella enterica isolates show high antibiotic resistance. Antibiotic resistance is one of the dangerous fears to human. In this

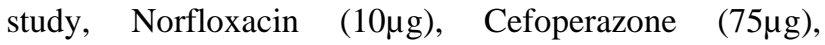
Ofloxacin $(5 \mu \mathrm{g})$, Nitrofurantoin $(300 \mu \mathrm{g})$, Chloramphenicol $(30 \mu \mathrm{g})$, Piperacillin $(100 \mu \mathrm{g})$ was found to be the greatest effect antimicrobials against Salmonella isolates in contrast, it showed high rates of resistance to Rifamycin

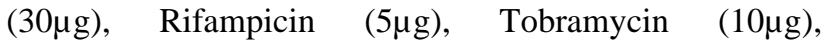
Erythromycin $(15 \mu \mathrm{g})$ and Novobiocin $(30 \mu \mathrm{g})$. MAR index of Salmonella enterica subsp. enterica strains isolated from examined raw camel milk samples is higher than 0.2, this indicated the isolate was come from high-hazard source of contamination and the abuse of antibiotics, while if the MAR is lower than 0.2 , this strain was identified from an area where antibiotics were used rarely or never used.

Bacteria can possess their antimicrobial resistance through either alteration, in the genomic sequences, or gene transferring mechanisms concerning Salmonella Johansson et al. (2020) found that translocatable units in Salmonella enterica for specific aminoglycoside, sulphonamide and tetracycline genes which have able to move between bacterial cells. The quick spread of antibiotic resistance between bacteria is largely due to the dissemination of antibiotic resistance genes by vertical or horizontal transfer mediated by plasmids, transposons, and/or integrons (Peterson and Kaur 2018).

\section{Conclusion}

Data from this study obviously showed that the bacteriological quality and safety of raw dromedary camel milk in Matrouh Governorate is relatively low. Raw dromedary camel milk obtained from the current production system is highly contaminated with pathogenic microorganisms including Salmonella spp. It is strongly recommended to apply appropriate hygienic measures during camel milking processing, good distribution, and transportation practices (GDTP) and good markets practices (GMP).

\section{Author's Contribution}

AA and EK conceptualized the idea. ES performed the experiment and collected the data and AA and EK analyzed the data. AA, EK, ES and HK wrote and edited the manuscript. AA, HK, EK and ES made funds available

\section{REFERENCES}

Altschul SF, Gish W, Miller W, Myers EW and Lipman DJ, 1990. Basic local alignment search tool. Journal of Molecular Biology 215: 403-410.

Aly SA and Elewa N, 2014. Hazards associated with dromedary camel milks. International Journal of Science and Nature 5: 412-417.

Bassuony NI, Abdel-Salam AF, Abdel-Ghany ZM, El-Karamany AMM, Atwa MA and Hassanein AM, 2014. Effect of camel milk on microbiological and chemical quality of soft cheese. Journal of Food and Dairy Sciences 5: 63-77.

Byrne L, Fisher I, Peters T, Mather A, Thomson N, Rosner B and Aiyedun V, 2014. A multi-country outbreak of Salmonella Newport gastroenteritis in Europe associated with Watermelon from Brazil, Confirmed by whole genome sequencing: October 2011 to January 2012. Eurosurveillance 19: 20866. https://doi.org/10.2807/1560-7917.ES2014.19. $\underline{31.20866}$

CDC, 2016. DC Multistate outbreak of Salmonella montevideo and Salmonella senftenberg infections linked to wonderfu pistachios Salmonella. March 2016. Available from www.cdc.gov/ Salmonella/montevideo-03-16 2016 Dec 29.

CLSI, 2018. Performance standards for antimicrobial susceptibility testing. 28th Ed. Egyptian standards for milk and milk products. 2005. Part 1: Raw milk, Egyptian Organization for Standards and Quality Control ES: 154$1 / 2005$.

Elbayoumi KM, HM Mekky, ZMSA Girh and MA Bosila, 2019. Effect of nano disinfectant and commercially available disinfectant classes on SPF-Egg experimentally infected with E. coli and Salmonella Species. International Journal of Veterinary Science 8: 243-248.

El-Demerdash HA and Al-Otaibi MM, 2012. Microbiological evaluation of raw camel milk and improvement of its keeping quality. American-Eurasian Journal of Agriculture and Environmental Science 12: 638-645.

EL-Ziny S and AL-Turki A, 2013. Microbiological quality and safety assessment of camel milk in Saudi Arabia. Applied Ecology and Environmental Research 11: 115-122.

Hassan KA, Elbourne LD, Li L, Hewawasam GHK, Liu Q, Jackson SM and Paulsen IT, 2015. An ace up their sleeve: A transcriptomic approach exposes the acei efflux protein of acinetobacter baumannii and reveals the drug efflux potential hidden in many microbial pathogens. Frontiers in Microbiology 6: 333. https://doi.org/10.3389/fmicb.2015. $\underline{00333}$ 
Henri C, Félix B, Guillier L, Leekitcharoenphon P, Michelon D, Mariet JF, Aarestrup FM, Mistou, MY, Hendriksen RS and Roussel S, 2016. Population genetic structure of Listeria monocytogenes strains as determined by pulsed-field gel electrophoresis and multilocus sequence typing. Applied and Environmental Microbiology 82: 5720-5728. https://doi.org/ 10.1128/AEM.00583-16.

Hojati Z, Zamanzad B, Hashemzadeh M, Molaie R and Gholipour A, 2013. Detection of fim $\mathrm{H}$ gene in uropathogenic Escherichia coli strains isolated from patients with urinary tract infection. Jundishapur Journal of Microbiology 8: e17520. https://doi.org/10.5812/jjm. 17520

Ismaili MA, Saidi B, Zahar M, Hamama A and Ezzaier R, 2016. Composition and microbial quality of raw camel milk produced in Morocco. Journal of the Saudi Society of Agricultural Sciences 18: 17-21. https://doi.org/10.1016/ j.jssas.2016.12.001

ISO 6579-3, 2014. Microbiology of the food chain - horizontal method for the detection, enumeration, and serotyping of Salmonella - Part 3: Guidelines for serotyping of Salmonella spp. International Organization for Standardization, Geneva, Switzerland.

ISO 6579-1, 2017. Microbiology of the food chain - horizontal method for the detection, enumeration, and serotyping of Salmonella - Part 1: Detection of Salmonella spp. International Organization for Standardization, Geneva, Switzerland.

Johansson MH, Bortolaia V, Tansirichaiya S, Aarestrup FM, Roberts A and Petersen TN, 2020. Detection of mobile genetic elements associated with antibiotic resistance in Salmonella Enterica using a newly developed web tool: mobile element finder. Journal of Antimicrobial Chemotherapy 76: 101-109. https://doi.org/10.1093/jac/ dkaa390

Kaabi H and AL-Yassari A, 2019. 16SrRNA sequencing as tool for identification of Salmonella spp. isolated from human diarrhea cases. Journal of Physics: Conference series IOP Publishing, Conference Series 1294: 062041. https://doi.org/ 10.1088/1742-6596/1294/6/062041.

Karshima NS, Pam VA, Bata SI, Dung PA and Paman ND, 2013. Isolation of Salmonella species from milk and locally processed milk products traded for human consumption and associated risk factors in Kanam, Plateau State, Nigeria. Journal of Animal Production Advances 3: 69-74. https://doi.org/10.5455/japa.20130330124355

Krumperman P, 1983. Multiple antibiotic resistance indexing of Escherichia coli to identify high-risk sources of fecal contamination of foods. Applied and Environmental Microbiology 46: 165-170.

Kumar S, Stecher G, Li M, Knyaz C and Tamura K, 2018. MEGA $\mathrm{X}$ : Molecular evolutionary genetics analysis across computing platforms. Molecular Biology and Evolution 35: 1547-1549. https://doi.org/10.1093/molbev/msy096

Kuźmińska-Bajor M, Grzymajło K and Ugorski M, 2015. Type 1 Fimbriae are important factors limiting the dissemination and colonization of mice by Salmonella enteritidis and contribute to the induction of intestinal inflammation during Salmonella invasion. Frontiers in Microbiology 6: 276. https://doi.org/10.3389/fmicb.2015.00276

Mahmoud MA, Megahed G, Yousef MS, Ali FAZ, Zaki, RS and Abdelhafeez, HH, 2020. Salmonella typhimurium triggered unilateral epididymo-orchitis and splenomegaly in a Holstein Bull in Assiut, Egypt: A case report. Pathogens 9: 314. https://doi.org/10.3390/pathogens 9040314
Murugkar HV, Rahman H and Dutta PK, 2003. Distribution of virulence genes in Salmonella serovars isolated from man and animals. Indian Journal of Medical Research 117: 66-70.

Noor M, Rotich V, Kiarie JW, Cheruiyot K and Kagira, JM, 2020. Prevalence, risk factors associated with brucellosis and presence of pathogenic bacteria isolated from camel milk in Garissa County, Kenya. South Asian Journal of Research in Microbiology 6: 42-52. https://doi.org/10.9734/sajrm/2020/ v6i430158

Olivera SD, Rodenbusch CR, Ce MC, Rocha SLS and Canal CW, 2003. Evaluation of selective and non-selective enrichment PCR procedures for Salmonella detection. Letters in Applied Microbiology 36: 217-221. https://doi.org/10.1046/j.1472765x.2003.01294.x.

Robertson J, Yoshida C, Kruczkiewicz P, Nadon C, Nichani A, Taboada EN and Nash J, 2018. Comprehensive assessment of the quality of Salmonella whole genome sequence data available in public sequence databases using the Salmonella in silico typing resource (SISTR). Microbial Genomics 4: e000151. https://doi.org/10.1099/mgen.0.000151

Sambrook J, Fritscgh EF and Mentiates, 1989. Molecular coloning. A laboratory manual. vol! Cold Spring Harbor Laboratotry Press, New York. Section 16.32-16.40. https://doi.org/10.1016/0307-4412(83)90068-7

Soliman S, Seida AA, El-Fakar SZ, Youssef YI and El-Jakee J, 2020. Pathogenicity of avian salmonellae in specific pathogen free chicks. International Journal of Veterinary Science 9: 36-41.

Peterson E and Kaur P, 2018. Antibiotic resistance mechanisms in bacteria: relationships between resistance determinants of antibiotic producers, environmental bacteria, and clinical pathogens. Frontiers in Microbiology 9: 2928. https://doi.org/10.3389/fmicb.2018.02928

Shaw KA, Wright K, Privett K, Holloman K, Levine S, McCombs $\mathrm{K}$ and Woolard D, 2020. Salmonellosis outbreak after a large-scale food event in Virginia, 2017. Public Health Reports 135: 668-675. https://doi.org/10.1177/0033354920 $\underline{944861}$

Uchiya K, Kamimura Y, Jusakon A and Nikai T, 2019. Salmonella fmbrial protein fim $\mathrm{H}$ is involved in expression of proinflammatory cytokines in a toll-like receptor 4dependent manner. Infection and Immunity 87: e00881-18. https://doi.org/10.1128/IAI.00881-18

WHO, 2018. Salmonella https://www.who.int/news-room/factsheets/detail/Salmonella-(non-typhoidal).

Yu J, Zhang Y, Li H, Yang H and Wei H, 2016. Sensitive and rapid detection of Staphylococcus aureus in milk via cell binding domain of lysin. Biosensors and Bioelectronics 77: 366-371. https://doi.org/10.1016/j.bios.2015.09.058.

Zhao X, Lin C, Wang J and Oh D, 2014. Advances in rapid detection methods for foodborne pathogens. Journal of Microbiology and Biotechnology 24: 297-312. https://doi.org/10.4014/jmb.1310.10013.

Zhao X, Wei C, Zhong J and Jin S, 2016. Research advance in rapid detection of foodborne Staphylococcus aureus. Biotechnology \& Biotechnological Equipment 30: 827-833. https://doi.org/10.1080/13102818.2016.1209433

Hassena AB, Haendiges J, Zormati S, Guermazi S, Gdoura R, Gonzalez-Escalona N. and Siala M, 2021. Virulence and resistance genes profiles and clonal relationships of nontyphoidal food-borne Salmonella Strains isolated in Tunisia by whole genome sequencing. International Journal of Food Microbiology 337: 108941. https://doi.org/10.1016/j.ijfood $\underline{\text { micro.2020.108941 }}$ 